\title{
GAMBARAN TINGKAT KEPUASAN WISATAWAN ASING TERHADAP MUTU PELAYANAN KESEHATAN GIGI DAN MULUT DI BALI DENTAL CLINIK 911 DENPASAR TAHUN 2020
}

I Nyoman Gejir ${ }^{1}$, Ida Ayu Dewi Kumala Ratih ${ }^{2}$, Ni Nengah Sumerti ${ }^{3}$, Dewa Ayu Perawati ${ }^{4}$

1,2,3 Dosen Jurusan Kesehatan Gigi Poltekkes Denpasar

4 Mahasiswa Jurusan Kesehatan Gigi Poltekkes Denpasar

\section{Abstract}

Bali Dental Clinic 911 is Dental and Oral Health Service which located in Denpasar. The kind of service in the Clinic, include; preventive, kurative, and rehabilitave in dental health, for Indeonesian and foreigns.The data shows that patients visiting in 2016 are 5,043, in 2017 are 5,830, and in 2018 are 6,350, majority patients from Austria. The goals of this research is to know the descriptive of satisfaction of foreigns tourism toward dental and oral services in Bali Dental Clinic 911 in 2020.

This is a descriptive research with survey. The respondents in this research were all foreigns tourism who were visit Bali Dental Clinic 911 Denpasar in March 2020, with the total number of respondents are 50.

The result of this research shows that: reliability demention with very satisfaction (91,5\%), Responsiveness demention with very satisfaction (87,3\%), assurance demention with very satisfaction (92\%), Emphaty demention with very satisfaction (90\%), tangibles demention with very satisfaction (85\%).

The conclussion of this research shows that majority foreigns tourism who were visit Bali Dental Clinic 911 Denpasar in March 2020 got very satisfaction services in dental and oral health.

Keywords : Satisfaction, Dental and Oral Health Services, Foreigns

\section{Pendahuluan}

Menurut Peraturan Pemerintah Nomor 76 Tahun 1996 tentang Penyelenggaraan Kepariwisataan, wisata merupakan kegiatan perjalanan atau sebagian dari kegiatan tersebut yang dilakukan secara sukarela serta bersifat sementara untuk menikmati objek dan daya tarik wisata. Menurut peraturan ini, pariwisata juga diartikan sebagai segala sesuatu yang berhubungan dengan wisata, termasuk pengusahaan objek dan daya tarik wisata serta usaha-usaha yang terkait di bidang tersebut (Presiden RI, 1996) dalam Wirawan, 2016) ${ }^{\mathbf{1}}$.

Ilmu pengetahuan dan praktik yang terkait dengan kedokteran dan kesehatan di daerah pariwisata sudah berkembang sangat pesat. Hal ini juga bisa digunakan sebagai dasar dalam memberikan batasan-batasan yang sesuai dan ruang lingkup yang tepat untuk masing-masing sub-disiplin ilmu yang ada. Keterkaitan berbagai disiplin dan subdisiplin yang sudah ada dalam kaitannya dengan identifikasi komponen-komponen utama dalam kesehatan pariwisata. Berdasarkan uraian di atas, maka dapat dikatakan bahwa ruang lingkup kesehatan pariwisata menjadi sangat luas, mencakup kesehatan wisatawan, masyarakat penjamu, pekerja di industri pariwisata, kawasan wisata, keamanan pangan daerah wisata, termasuk juga berbagai kebijakan terkait kesehatan dan pariwisata ${ }^{1}$.

Persaingan dengan negara lain dalam ilmu kesehatan khususnya dalam kemampuan menggaet "wisatawan asing" untuk berobat ke Indonesia masih sulit. Indonesia bukan sebagai "guide" tamu untuk berobat, melainkan menjadi turis yang berobat ke negara lain. Menurut data Kementerian Kesehatan, lebih dari 600.000 orang Indonesia berobat ke luar negeri setiap tahun. Hal ini menyebabkan PDB yang diterima 
oleh negara dalam bidang kesehatan cukup rendah hanya sekitar 2,7 persen menurut data World Bank pada tahun 2012 dan perkembangannya relatif stagnan. Sangat kecil dibandingkan rata-rata PDB kesehatan negara ASEAN sebesar 3,9 persen (Wihardana, 2015).

Beberapa negara dalam rangka menarik wisatawan mereka menawarkan paket kesehatan dan berlibur. Hal ini menarik sebab bagi wisatawan yang ingin mendapatkan perawatan kesehatan dapat berlibur ke suatu negara sehingga dapat memanfaatkan waktu cuti sakitnya dengan berlibur. Beberapa rumah sakit yang sudah siap untuk menjadi rumah sakit internasional dapat melakukan promosi secara terpadu dengan instansi terkait, seperti dinas pariwisata, kantor kedutaan di negara sahabat, hotel-hotel dan organisasi internasional lainnya. Dengan demikian maka akan lebih dikenal fasilitas kesehatan dan pariwisata yang kita miliki. Tentunya hal ini juga harus ditunjang olah kesiapan sumber daya manusia, fasilitas yang memadai dan sarana promosi yang baik (Ikayana Kesmas, 2008) ${ }^{2}$.

Penurunan pemanfaatan terhadap pelayanan kesehatan, disebabkan oleh akses pelayanan kesehatan meningkat namun mutunya masih rendah atau kurangnya efisiensi dan efektifitas provider dalam memberikan jasa pelayanan terhadap masyarakat. Permasalahan-permasalahan tersebut dapat diketahui dengan semakin banyaknya terdengar keluhan-keluhan masyarakat tentang mutu pelayanan kesehatan mulai dari keadaan fisik yang jelek, sikap petugas atau cara mereka dilayani, sistem birokrasi yang rumit, mutu perawatan dan pengobatan yang rendah, jam kerja yang singkat yang menyebabkan pasien tidak dapat dilayani. Penurunan pemanfaatan terhadap pelayanan kesehatan gigi dan mulut juga dipengaruhi oleh tingkat kepuasan pasien terhadap mutu pelayanan kesehatan gigi dan mulut (Muninjaya, 2011) ${ }^{4}$.

Pulau Bali merupakan objek wisata yang sudah dikenal luas. Banyak wisatawan yang berkunjung ke Bali setiap tahunnya dengan berbagai tujuan, seperti: berlibur, memperoleh pelayanan kesehatan, dan sebagainya yang memberikan keuntungan devisa bagi pemerintah dan para pelaku pariwisata (Ikayana Kesmas, 2008) ${ }^{2}$. Menurut Dinas Pariwisata, kunjungan wisatawan asing ke Bali tahun 2016 mencapai 5.043 orang, tahun 2017 sebanyak 5.830, dan tahun 2018 sebanyak 6.830. Wisatawan tersebut paling banyak berasal dari negara Australia.

Apabila ditinjau dari bidang kesehatan, maka tantangan yang dihadapi terkait dengan kesehatan pariwisata tersebut adalah pada pemenuhan kebutuhan akan fasilitas pelayanan kesehatan, tenaga medis, tenaga kesehatan lain yang memiliki kapabilitas terkait kesehatan wisata (Wirawan, 2016) ${ }^{\mathbf{1}}$. Suatu lembaga pelayanan kesehatan yang dapat menyelenggarakan pelayanan kesehatan yang bermutu, maka akan dapat menimbulkan kepuasan bagi pasiennya (Kotler, 2002) ${ }^{3}$.

Bali Dental Clinik 911 merupakan salah satu tempat pelayanan di bidang kesehatan gigi dan mulut yang berlokasi di jalan Patimura no. 4 Denpasar. Bentuk pelayanan yang diberikan meliputi pelayanan preventif, kuratif, dan rehabilitatif untuk masyarakat Indonesia dan wisatawan asing. Data yang diperoleh untuk jumlah kunjungan pasien dari tahun 2016 hingga tahun 2019 terjadi peningkatan, tetapi ada penurunan pada jumlah kunjungan pasien baru.

Berdasarkan hasil wawancara dengan beberapa pasien asing yang datang berobat di Bali Dental Clinik 911, salah satu yang menjadi alasan mereka datang berobat adalah harga yang jauh lebih murah jika dibandingkan mereka berobat di negaranya. Tujuan penelitian ini adalah untuk mengetahui gambaran tingkat kepuasan Wisatawan Asing terhadap mutu pelayanan kesehatan gigi dan mulut di Bali Dental Clinik 911 Denpasar. 


\section{Metode Penelitian}

Penelitian ini merupakan penelitian deskriptif, dengan desain survai dengan bantuan kuesioner. Penelitian dilaksanakan pada bulan Maret dan April 2020, di Bali Dental Clinic 911 Denpasar. Populasi penelitian ini adalah semua wisatawan yang datang untuk berobat di Bali Dental Clinic 911 Denpasar. Instrumen penelitian menggunakan lembar kuesioner tentang tingkat kepuasan. Tingkat kepusan diukur dengan demensi Reability sebanyak 4 pertanyaan , dimensi responsiveness sebanyak 3 pertanyaan, dimensi assurance sebanyak 4 pertanyaan, dimensi empathy sebanyak 3 pertanyaan dan dimensi tangibles sebanyak 4 pertanyaan.

Penentuan besar sampel menggunakan sampel Target, yaitu minimal 30 responden, apabila belum mencapai 30 maka masa pengumpulan data akan diperpanjang. Pengambilan sampel dalam penelitian ini adalah dengan accidental sampling, yaitu pengambilan sampel/responden ataupun kasus secara kebetulan tersedia (Riyanto, 2013) ${ }^{\mathbf{5}}$. Kriteria inklusi sampel adalah : Warga Negara Asing, umur $\geq 18$ tahun, bisa membaca dan menulis latin, dan bersedia menjadi responden. Hasil pengumpulan data selanjutnya dianalisis dengan statistic univariat, yaitu untuk mengetahui frekuensi dan persentase kepuasan.

\section{Hasil dan Pembahasan}

Bali Dental Clinic 911 berdiri pada tahun 2002 yang berlokasi di Jl. Patimura no 4 - 6 Denpasar, Desa Dangin Puri Kaja, Kec. Denpasar Utara, Kota Denpasar. Klinik merupakan salah satu tempat pelayanan di bidang kesehatan gigi dan mulut dengan bentuk pelayanan yang berikan meliputi pelayanan preventif, kuratif, dan rehabilitatif untuk masyarakat Indonesia dan wisatawan asing. Bali Dental Clinic 911 dipimpin oleh seorang dokter gigi dengan 35 orang karyawan, yang terdiri dari 12 drg dan 12 perawat gigi, satu orang Apoteker, sertasepuluh orang tenaga non medis. Fasilitas yang tersedia antara lain: sepuluh ruang pemeriksaan dan perawatan, ruang radiologi, satu ruang sterilisasi, satu ruang apotik, dua ruang tunggu, satu ruang Direktur, satu ruang karyawan, satu ruang arsip, satu ruang laktasi, dua toilet, serta dental laboratory dengan 20 karyawan untuk menunjang pelayanan kesehatan gigi.

Berdasarkan hasil pengumpulan data, selanjutnya dianalisis secara univariat diperoleh hasil sebagai berikut :

\section{Karakteristik subyek penelitian}

Gambar 1. Karakteristik Responden Berdasarkan Umur

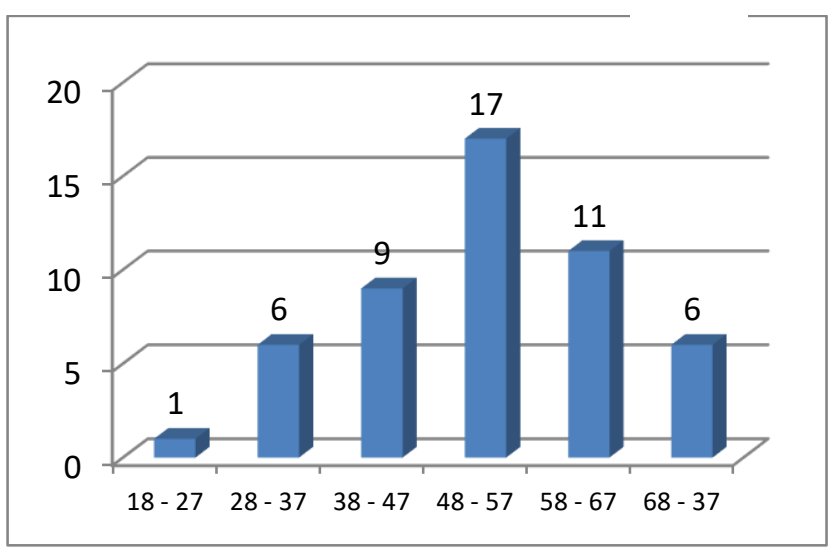

Gambar 1 menunjukkan bahwa berdasarkan umur, paling banyak responden berumur 48-57 tahun sebanyak 17 orang (34\%) dan paling sedikit umur 18-27 tahun sebanyak 1 responden (2\%).

\section{Hasil pengamatan terhadap obyek penelitian}

Hasil pengamatan terhadap kepuasan wisatawan asing yang berkunjung di Bali Dental Clinic 911 Denpasar pada setiap dimensi disajikan pada tabel-tabel berikut : 
Tabel 4. Kepuasan Responden Menurut Dimensi Reliability

\begin{tabular}{|c|c|c|c|c|c|c|c|c|c|}
\hline \multirow{3}{*}{ No } & \multirow{3}{*}{$\begin{array}{l}\text { Dimensi Kehandalan } \\
\quad \text { (Reliability }\end{array}$} & \multicolumn{8}{|c|}{ Tingkat Kepuasan } \\
\hline & & \multicolumn{2}{|c|}{ SP } & \multicolumn{2}{|c|}{$\mathrm{P}$} & \multicolumn{2}{|c|}{$\mathrm{TP}$} & \multicolumn{2}{|c|}{ STP } \\
\hline & & $\mathrm{n}$ & $\%$ & $\mathrm{n}$ & $\%$ & $\mathrm{n}$ & $\%$ & $\mathrm{n}$ & $\%$ \\
\hline 1 & $\begin{array}{l}\text { Prosedur penerimaan } \\
\text { pasien yang cepat dan } \\
\text { tepat. }\end{array}$ & 44 & $88 \%$ & 6 & $12 \%$ & 0 & 0 & 0 & 0 \\
\hline 2 & $\begin{array}{l}\text { Pelayanan pemeriksaan, } \\
\text { pengobatanan, dan } \\
\text { perawatan yang cepat } \\
\text { dan tepat. }\end{array}$ & 47 & $94 \%$ & 3 & $6 \%$ & 0 & 0 & 0 & 0 \\
\hline 3 & $\begin{array}{l}\text { Jadwal pelayanan di } \\
\text { jalankan dengan tepat. }\end{array}$ & 45 & $90 \%$ & 5 & $10 \%$ & 0 & 0 & 0 & 0 \\
\hline 4 & $\begin{array}{l}\text { Prosedur pelayanan tidak } \\
\text { berbelit-belit }\end{array}$ & 47 & $94 \%$ & 3 & $6 \%$ & 0 & 0 & 0 & 0 \\
\hline
\end{tabular}

Tabel 1 menunjukan bahwa menurut dimensi reliability, mayoritas menyatakan sangat puas. Sub dimensi pelayanan pemeriksaan, dan perawatan yang cepat dan tepat, serta sub dimensi prosedur pelayanan tidak berbelit- belit, masing masing memperoleh kriteria sangat puas sebanyak $94 \%$, serta tidak ada wisatawan asing yang menyatakan tidak puas dan sangat tidak puas untuk dimensi reliability.

Tabel 2 Kepuasan Responden Menurut Dimensi Responsiveness

\begin{tabular}{llllllllll}
\hline No & $\begin{array}{l}\text { Dimensi Daya Tanggap } \\
\text { (Responsiveness) }\end{array}$ & \multicolumn{7}{c}{ Tingkat Kepuasan } \\
\cline { 2 - 9 } & $\mathrm{n}$ & $\mathrm{SP}$ & $\mathrm{n}$ & $\%$ & $\mathrm{n}$ & $\%$ & $\mathrm{n}$ & $\%$ \\
\hline 1 & $\begin{array}{l}\text { Kemampuan dokter dan } \\
\text { perawat untuk cepat } \\
\text { tanggap menyelesaikan }\end{array}$ & 45 & $90 \%$ & 5 & $10 \%$ & 0 & 0 & 0 & 0 \\
\hline $\begin{array}{l}\text { keluhan pasien. } \\
\text { Petugas memberikan } \\
\text { informasi yang jelas dan } \\
\text { mudah dimengerti. }\end{array}$ & 43 & $86 \%$ & 7 & $14 \%$ & 0 & 0 & 0 & 0 \\
\hline $\begin{array}{l}\text { Tindakan cepat pada } \\
\text { pasien yang } \\
\text { membutuhkan. }\end{array}$ & 43 & $86 \%$ & 7 & $14 \%$ & 0 & 0 & 0 & 0 \\
\hline
\end{tabular}

Tabel 2 menunjukan bahwa menurut dimensi responsiveness, semua sub dimensi mayoritas menyatakan sangat puas. Sub dimensi kemampuan dokter dan perawat untuk cepat tanggap menyelesaikan keluhan pasien memperoleh kreteria sangat puas sebanyak $90 \%$, serta tidak ada wisatawan asing yang menyatakan tidak puas dan sangat tidak puas untuk dimensi responsiveness. 
Tabel 3. Kepuasan Responden Menurut Dimensi Assurance

\begin{tabular}{|c|c|c|c|c|c|c|c|c|c|}
\hline \multirow[t]{3}{*}{ No } & \multirow{3}{*}{$\begin{array}{l}\text { Dimensi Jaminan } \\
\text { (Assurance) }\end{array}$} & \multicolumn{8}{|c|}{ Tingkat Kepuasan } \\
\hline & & \multicolumn{2}{|c|}{ SP } & \multicolumn{2}{|c|}{$\mathrm{P}$} & \multicolumn{2}{|c|}{$\mathrm{TP}$} & \multicolumn{2}{|c|}{ STP } \\
\hline & & $\mathrm{n}$ & $\%$ & $\mathrm{n}$ & $\%$ & $\mathrm{n}$ & $\%$ & $\mathrm{n}$ & $\%$ \\
\hline 1 & $\begin{array}{l}\text { Dokter memiliki } \\
\text { pengetahuan dan } \\
\text { kemampuan dalam } \\
\text { menetapkan penyakit } \\
\text { pasien. }\end{array}$ & 45 & $90 \%$ & 5 & $10 \%$ & 0 & 0 & 0 & 0 \\
\hline 2 & $\begin{array}{l}\text { Dokter, perawat, dan } \\
\text { petugas lainnya terampil } \\
\text { dalam bekerja } \\
\text { melaksanakan tugasnya. }\end{array}$ & 46 & $92 \%$ & 4 & $8 \%$ & 0 & 0 & 0 & 0 \\
\hline 3 & $\begin{array}{l}\text { Pelayanan sopan, ramah } \\
\text { dan jujur. }\end{array}$ & 47 & $94 \%$ & 3 & $6 \%$ & 0 & 0 & 0 & 0 \\
\hline 4 & $\begin{array}{l}\text { Adanya jaminan } \\
\text { keamanan pelayanan dan } \\
\text { kepercayaan terhadap } \\
\text { pelayanan. }\end{array}$ & 46 & $92 \%$ & 4 & $8 \%$ & 0 & 0 & 0 & 0 \\
\hline
\end{tabular}

Tabel 3 menunjukan bahwa menurut dimensi assurance., semua sub dimensi mayoritas menyatakan sangat puas. Sub dimensi pelayanan sopan, ramah dan jujurmemperoleh kreteria sangat puas sebanyak 94\%, serta tidak ada wisatawan asing yang menyatakan tidak puas dan sangat tidak puas untuk dimensi assurance.

Tabel 4. Kepuasan Responden Menurut Dimensi Empathy

\begin{tabular}{|c|c|c|c|c|c|c|c|c|c|}
\hline \multirow[t]{3}{*}{ No } & \multirow{3}{*}{$\begin{array}{c}\text { Dimensi Empati } \\
\text { (Empathy) }\end{array}$} & \multicolumn{8}{|c|}{ Tingkat Kepuasan } \\
\hline & & \multicolumn{2}{|c|}{ SP } & \multicolumn{2}{|c|}{$\mathrm{P}$} & \multicolumn{2}{|c|}{ TP } & \multicolumn{2}{|c|}{ STP } \\
\hline & & $\mathrm{n}$ & $\%$ & $\mathrm{n}$ & $\%$ & $\mathrm{n}$ & $\%$ & $\mathrm{n}$ & $\%$ \\
\hline 1 & Memberikan perhatian & & & & & & & & \\
\hline & $\begin{array}{l}\text { khusus kepada setiap } \\
\text { pasien. }\end{array}$ & 45 & $90 \%$ & 5 & $10 \%$ & 0 & 0 & 0 & 0 \\
\hline 2 & $\begin{array}{l}\text { Memperhatikan keluhan } \\
\text { pasien dan keluarganya }\end{array}$ & 45 & $90 \%$ & 5 & $10 \%$ & 0 & 0 & 0 & 0 \\
\hline 3 & $\begin{array}{l}\text { Pelayanan kepada semua } \\
\text { pasien tidak memandang } \\
\text { status sosial, ekonomi } \\
\text { dan Iain-lain. }\end{array}$ & 45 & $90 \%$ & 5 & $10 \%$ & 0 & 0 & 0 & 0 \\
\hline
\end{tabular}

Tabel 4 menunjukan bahwa menurut dimensi empathy semua sub dimensi mayoritas menyatakan sangat puas. Seluruh sub dimensinya memperoleh kreteria sangat puas sebanyak $90 \%$, serta tidak ada wisatawan asing yang menyatakan tidak puas dan sangat tidak puas untuk dimensi empathy. 
Tabel 5. Kepuasan Responden Menurut Dimensi Tangibles

\begin{tabular}{|c|c|c|c|c|c|c|c|c|c|}
\hline \multirow[t]{3}{*}{ No } & \multirow{3}{*}{$\begin{array}{c}\text { Dimensi Bukti Fisik } \\
\text { (Tangibles) }\end{array}$} & \multicolumn{8}{|c|}{ Tingkat Kepuasan } \\
\hline & & \multicolumn{2}{|c|}{ SP } & \multicolumn{2}{|c|}{$\mathrm{P}$} & \multicolumn{2}{|c|}{$\mathrm{TP}$} & \multicolumn{2}{|c|}{ STP } \\
\hline & & $\mathrm{n}$ & $\%$ & $\mathrm{~N}$ & $\%$ & $\mathrm{n}$ & $\%$ & $\mathrm{n}$ & $\%$ \\
\hline 1 & $\begin{array}{l}\text { Ruangan bersih, rapi, dan } \\
\text { nyaman. }\end{array}$ & 42 & $84 \%$ & 8 & $16 \%$ & 0 & 0 & 0 & 0 \\
\hline 2 & $\begin{array}{l}\text { Eksterior dan interior } \\
\text { ruangan tertata dengan } \\
\text { baik. }\end{array}$ & 41 & $82 \%$ & 9 & $18 \%$ & 0 & 0 & 0 & 0 \\
\hline 3 & $\begin{array}{l}\text { Alat-alat yang dipakai } \\
\text { bersih dan siap pakai. }\end{array}$ & 44 & $88 \%$ & 6 & $12 \%$ & 0 & 0 & 0 & 0 \\
\hline 4 & $\begin{array}{l}\text { Penampilan petugas rapi } \\
\text { dan bersih. }\end{array}$ & 43 & $86 \%$ & 7 & $14 \%$ & 0 & 0 & 0 & 0 \\
\hline
\end{tabular}

Tabel 5 menunjukan bahwa menurut dimensi tangibles, semua sub dimensi mayoritas menyatakan sangat puas. Sub dimensi alat-alat yang dipakai bersih dan siap pakai memperoleh kriteria sangat puas sebanyak $88 \%$, serta tidak ada wisatawan asing yang menyatakan tidak puas dan sangat tidak puas untuk dimensi tangibles.

\section{Pembahasan}

Berdasarkan hasil pengumpulan data tentang gambaran kepuasan wisatawan asing yang dilakukan terhadap 50 responden (100\%) pada bulan maret 2020 terhadap wisatawan asing warga negara australia dengan umur $\leq 18$ yang dilakukan di Bali Dental Clinic 911 Denpasar diperoleh gambaran hasil penelitian menunjukkan bahwa kelompok umur wisatawan asing yang paling banyak melakukan perawatan gigi dan mulut di Bali Dental Clinic 911 Denpasar tahun 2020 yaitu umur antara 48-57 tahun dengan 17 orang atau sebesar $34 \%$, sedangkan kelompok umur yang paling sedikit melakukan perawatan gigi dan mulut terdapat pada kelompok umur 18-27 tahun dengan 1 orang atau sebesar $2 \%$.

Gambaran hasil penelitian mengenai tingkat kepuasan wisatawan asing terhadap mutu pelayanan kesehatan gigi dan mulut di Bali Dental Clinic 911 Denpasar Tahun 2020 ditinjau dari dimensi kepuasan adalah sebagai berikut:

\section{Dimensi reliability}

Menurut dimensi reliability, semua sub dimensi mayoritas menyatakan sangat puas. Sub dimensi pelayanan pemeriksaan, dan perawatan yang cepat dan tepat, serta sub dimensi prosedur pelayanan tidak berbelitbelit, masing masing memperoleh kriteria sangat puas sebanyak 94\%, serta tidak ada wisatawan asing yang menyatakan tidak puas dan sangat tidak puas untuk dimensi reliability. Hal ini mungkin disebabkan karena tenaga yang bertugas di Bali Dental Clinic 911 Denpasar sudah memiliki prosedur penerimaan dan pelayanan yang mendukung kepuasan pasien saat pertama kali memasuki fasilitas pelayanan kesehatan. Hasil penelitian ini didukung oleh pendapat (Parasuraman, dkk. (1988) dalam Peprah \& Atarah, 2014; Wira, dkk., 2014) yang menyatakan bahwa kehandalan dan kemampuan penyelenggara pelayanan kesehatan untuk memberikan pelayanan yang segera dan akurat sejak identifikasi dan pertama kali tanpa membuat kesalahan apapun dan memuaskan sangat diperlukan untuk kepuasan pelanggan ${ }^{\mathbf{1 0}}$.

\section{Dimensi resposiveness}

Menurut dimensi responsiveness, semua sub dimensi mayoritas menyatakan sangat 
puas. Sub dimensi kemampuan dokter dan perawat untuk cepat tanggap menyelesaikan keluhan pasien memperoleh kreteria sangat puas sebanyak 90\%, serta tidak ada wisatawan asing yang menyatakan tidak puas dan sangat tidak puas untuk dimensi responsiveness. Hal ini mungkin disebabkan karena memiliki SOP yang harus dijadikan pedoman dalam menangani pasien, sehingga semua tenaga kesehatan gigi yang bertugas memiliki sikap tanggap dalam menangani keluhan pasien. Menurut Tjiptono dan Diana (2019), salah satu upaya meningkatkan kepuasan pelanggan adalah dengan menindaklanjuti setiap keluhan dari pelanggan dan menunjukkan kepada mereka bahwa perusahaan siap mendengarkan dan siap mengubah prosedur operasional dalam rangka meningkatkan kepuasan pelanggan ${ }^{6}$.

\section{Dimensi assurance}

Menurut dimensi assurance., semua sub dimensi mayoritas menyatakan sangat puas. Sub dimensi pelayanan sopan, ramah dan jujurmemperoleh kreteria sangat puas sebanyak 94\%, serta tidak ada wisatawan asing yang menyatakan tidak puas dan sangat tidak puas untuk dimensi assurance. Hal ini mungkin disebabkan karena Dokter memiliki pengetahuan dan kemampuan dalam menetapkan penyakit pasien, dokter, perawat, dan petugas lainnya terampil dalam bekerja melaksanakan tugasnya, pelayanan yang sopan dan ramah, dan adanya jaminan keamanan pelayanan dan kepercayaan terhadap pelayanan merupakan faktor-faktor yang termasuk dalam dimensi assurance. Hasil penelitian ini didukung oleh pendapat Parish (2005), bahwa dalam penelitian yang dilakukan secara survai memperoleh hasil faktor-faktor yang mempengaruhi kepuasan pasien terhadap pelayanan kesehatan antara lain adalah sikap ramah pemberi pelayanan, serta keberhasilan dalam memberi perawatan yang dibutuhkan pasien ${ }^{7}$.

\section{Dimensi empathy}

Menurut dimensi empathy semua sub dimensi mayoritas menyatakan sangat puas. Seluruh sub dimensinya memperoleh kreteria sangat puas sebanyak $90 \%$, serta tidak ada wisatawan asing yang menyatakan tidak puas dan sangat tidak puas untuk dimensi empathy. Hal ini kemungkinan disebabkan karena tenaga kesehatan gigi yang bertugas mampu memberikan perhatian khusus kepada setiap pasien, memperhatikan keluhan pasien dan keluarganya, pelayanan kepada semua pasien tidak memandang status sosial maupun ekonomi. Hasil penelitian ini sejalan dengan penelitian I Nyoman Gejir dan I Gede Surya Kencana (2018), yang menyatakan bahwa sebesar $84 \%$ wisatawan asing yang berkunjung ke Poliklinik Gigi dan Rumah Sakit di Bali menyatakan sangat puas ${ }^{8}$. Hasil ini didukung pula oleh pendapat Tjiptono dan Diana (2019) yang menyatakan bahwa untuk meningkatkan kepuasan pelanggan dapat dilakukan Acknowledging, yaitu berusaha menunjukkan kepada pelanggan bahwa mereka dikenal secara personal. Hal ini dapat dilakukan melalui upaya merespon setiap komunikasi atau korespondensi dari pelanggan secepat mungkin ${ }^{6}$.

\section{Dimensi tangibles}

Menurut dimensi tangibles, semua sub dimensi mayoritas menyatakan sangat puas. Sub dimensi alat-alat yang dipakai bersih dan siap pakai memperoleh kriteria sangat puas sebanyak $88 \%$, serta tidak ada wisatawan asing yang menyatakan tidak puas dan sangat tidak puas untuk dimensi tangibles. Hal ini mungkin disebabkan karena fasilitas yang tersedia dalam keadaan prima, misalnya: ruangan bersih, rapi, dan nyaman, eksterior dan interior ruangan tertata dengan baik, alatalat yang dipakai bersih dan siap pakai, dan penampilan petugas rapi dan bersih merupakan faktor-faktor yang termasuk dalam dimensi tangibles. Hasil penelitian ini sesuai dengan KEPMENPAN NO.25/M/PAN/2/2004, tentang indeks kepuasan masyarakat, yang menyatakan 
bahwa salah satu faktor pendukung kepuasan pasien adalah tersedianya sarana prasarana yang baik, meliputi: kenyamanan lingkungan, yaitu kondisi sarana dan prasarana pelayanan yang bersih, rapi dan teratur, sehingga dapat memberikan rasa nyaman kepada penerima pelayanan?.

\section{Simpulan}

Berdasarkan hasil penelitian gambaran tingkat kepuasan wisatawan asing terhadap mutu pelayanan kesehatan gigi dan mulut di Bali Dental Clinic 911 Denpasar tahun 2020 dapat disimpulkan bahwa semua dimensi kepuasan, meliputi : reliability, responsiveness, asuurance, empathy, dan tangibles sebagian besar dinilai sangat memuaskan, dan tidak ada yang menyatakan tidak puas terhadap pelayanan yang diterima. Berdasarkan hasil tersebut disarankan agar mutu pelayanan di Bali Dental Clinic 911 dapat dipertahankan, serta bila perlu ditingkatkan dengan mengupayakan sumber daya yang ada.

\section{Daftar Pustaka}

1. Wirawan, IMA., 2016. Kesehatan Pariwisata: Aspek Kesehatan Masyarakat Di Daerah Tujuan Wisata. Arc.Com.Health, 3 (1): ix-xiv.

2. Ikatan Alumni Kesehatan Masyarakat Universitas Udayana, Bali, 2008. Peranan Kesehatan Pariwisata dalam Menunjang Program Visit Indonesia Year 2008. Ikayana Kesmas.

3. Kotler, P., 2002. Management Pemasaran, Jakarta : Prehalindo.
4. Muninjaya, A.A. Gede. 2011. Manajemen Mutu Pelayanan Kesehatan, Jakarta : EGC

5. Riyanto, A., 2013, Statistik Deskriptif Untuk Kesehatan, Yogyakarta : Nuha Medika.

6. Tjiptono, F dan Diana, A, 2019, Kepuasan Pelanggan, Konsep, Pengukuran, dan Strategi, Yogyakarta: Andi Offset.

7. Parrish, B., dkk., 2015. Weighting Patient Satisfaction Factors To Inform Health Care Providers Of The Patient Experience In The Age Of Social Media Consumer Sentiment. Patient Experience Journal, 2 (1): 82-92.

8. Gejir, I.N dan Kencana, S.I.G., 2018. Hasil Penelitian, Evaluasi Tingkat Kepuasan Wisatawan Asing Terhadap Mutu Pelayanan Kesehatan Gigi Dan Mulut Pada Klinik Dan Rumah Sakit di Bali, Denpasar: TP

9. Kepmenpan Nomor 25/Kep/ M.PAN/2/2004. Pedoman Penyusunan Indeks Kepuasan Masyarakat Unit Pelayanan Instansi Pemerintah.

10. Wira, D., dkk., 2014. Hubungan antara Persepsi Daya Tanggap Dan Persepsi Empati dengan Kepuasan Pasien di RSUD Wangaya Denpasar. Public Health and Preventive Medicine Archive, 2 (2): 150155. 